asymmetric information. Drivers were not disclosing their ride sharing activity to their personal auto insurers in order to avoid premium hikes, thereby risking fraud charges and insurance cancellation. The Uber driver rating system prompted drivers to tolerate difficult and hazardous rides to avoid the risk of low ratings by passengers. Drivers received incentives to drive even when they were trying to sign off. Finally, passenger destination was blinded to the driver, creating asymmetric information conditions that limited driver choice of ride destination and duration.

Conclusion Many of the driver risks related to drivers' own precarious economic situations and need for income together with pressures from the Uber app to engage in unsafe working conditions. Although Uber drivers are touted as only 'sharing' a ride and as their 'own boss', in practice their driving activities were strongly governed by the Uber app

\section{INTERVENTIONS IN INFORMAL SECTORS: A PARTICIPATORY ERGONOMICS APPROACH}

Somnath Gangopadhyay*. Professor; Occupational Ergonomics Laboratory, Department of Physiology, University of Calcutta, Calcutta, India

\subsection{6/oemed-2018-ICOHabstracts. 1408}

Introduction A large number of work forces in Asia (85\%) are directly involved in informal sectors, whereas among the other continents, Africa contributes $57 \%$ to informal work. The most of the employees are contractual or casual. The labour laws are mostly, not applicable in the informal sectors. There are lack of occupational safety and health awareness among them, which include, less attention to industrial hygiene, poor housekeeping and poor employee protection.

This tremendous work force directly links with work pressure. Time is calculated as accumulation of money. Work and time will become the stress to these workers. Production has great importance than safety and health, so, human comfort is greatly neglected. A demand for investigation on health and safety is a common and genuine demand of informal sectors. In 2001, in International Labour Conference, the challenge for integration of Informal economy with formal economy was greatly discussed. We should include another challenge: the applications of work comfort in informal sectors.

Methods A large number of these workers are suffering from different types of work related disorders. It is observed that through the application of low cost interventions their conditions may be improved. Through the participatory ergonomics approach, several interventions are designed and applied in different informal sectors of India. A detailed study is made on the identification of efficacies of these interventions.

Result Surprisingly observed, low cost health interventions can improve the productivity of informal sectors up to 30\%. The work-related musculoskeletal disorders (WMSDs) are also prevented.

Discussion It is essential and important to apply the exact interventions and to find out and behavioural approaches of the users towards the utilizations of interventions. As informal sectors are increasing steadily in different developing countries so to give the workers comfort is becoming a challenge of these parts of the globe.

\section{SMALL ITALIAN ENTERPRISES AND THEIR EFFECTIVE APPLICATION OF LAWS CONCERNING OCCUPATIONAL HEALTH: A SIX YEARS STUDY}

${ }^{1}$ Marco Italo D'Orso, ${ }^{1}$ Michele Augusto Riva, ${ }^{2}$ Piatrizia Fabretto, ${ }^{3}$ Alessandra Messa, ${ }^{4}$ Letizia Colais, ${ }^{1}$ Giancarlo Cesana. ${ }^{1}$ University Of Milan Bicocca, Monza, Italy; ${ }^{2}$ Consortium for the development of Occupational and Environmental Medicine, Monza, Italy; ${ }^{3}$ Synlab Italia S.r.l., Monza, Italy; ${ }^{4}$ Institute of Public Health - Section of Occupational Health, Catholic University of the Sacred Heart, Rome, Italy

\subsection{6/oemed-2018-ICOHabstracts. 1409}

Introduction Small enterprises are the majority of productive activities in Italy. For a small enterprise activation of regulations prescribed by European law concerning occupational health promotion is difficult and proportionally expensive. This fact could originate a delay in application of preventative laws comparing with what usually happens in bigger firms.

Methods State of application of laws concerning occupational health and safety in Italy has been evaluated a first time in 2011 in 1458 small enterprises (less than 50 workers). Evaluation has been repeated in 2017 in same firms to verify the possible differences in application of laws carried out in this six years period. For every enterprise we verified presence of a regular program of occupational medicine carried out by an Occupational Health Doctor according to guidelines of Italian Occupational Health Association. We also evaluated Occupational Doctors' role in risk assessment. We evaluated adoption of correct personal protective devices, their use and specific individual formation programs.

We also studied legal problems eventually found in small firms carrying out these programs.

Results Only in $21.8 \%$ of firms evaluated we evidenced complete and adequate applications of laws. In $81.9 \%$ firms correct occupational health programs were regularly carried out. Occupational Health Doctors have been involved in risk assessment in $71,8 \%$ firms. Personal protective devices were adopted and used only in 55,4\% firms. Specific individual formation programs for workers were carried out in $48,5 \%$ firms. We present data divided for different productive sectors comparing them with data collected in 2011.

Discussion Small enterprises respect of laws concerning workers' health and safety is increased comparing with what resulted in 2011 but it is still not satisfactory. A more active Occupational Health Doctors role could increase workers' safety and health in these firms. This result could be obtained only increasing employers' and employees' cultural specific level.

\section{BRINGING OHS CLOSER TO THE CHANGING WORLD OF WORK: RESEARCH, ADVOCACY AND INTERVENTION WITH INFORMAL WORKERS IN SEVEN COUNTRIES}

${ }^{1}$ Francie Lund ${ }^{*},{ }^{2}$ Demetria Tsoutouras. 'Women in Informal Employment, Globalising and Organising, Durban, South Africa; ${ }^{2}$ Women in Informal Employment, Globalising and Organising, Ottawa, Canada

\subsection{6/oemed-2018-ICOHabstracts. 1410}

Introduction The world of work is changing, and the size of the informal economy increasing. Occupational health and safety (OHS) was designed for formal workers in formal firms and workplaces, with legislation governing norms and 